\title{
REVERSAL BY ACUPUNCTURE OF CARDIOVASCULAR DEPRESSION INDUCED WITH MORPHINE DURING HALOTHANE ANAESTHESIA IN DOGS
}

\author{
Do Chil Lee, Donald H. Clifford, Myung O. Lee and Leonard Nelson
}

\begin{abstract}
The cardiovascular effects of morphine sulphate and/or acupuncture by means of electrocautery at Jen Chung (Go-26) were studied in 35 dogs. All animals were maintained under anaesthesia with halothane 0.75 per cent supplemented by the intravenous administration of succinylcholine to allow controlled ventilation during a two hour period of monitoring. Cardiac output, stroke volume, heart rate, mean arterial pressure, pulse pressure, central venous pressure, total peripheral resistance, $\left[\mathrm{H}^{+}\right](\mathrm{pH}) \mathrm{Pa}_{\mathrm{CO}_{2}}, \mathrm{~Pa}_{\mathrm{O}_{2}}$ and base deficit were measured in each dog.

Morphine $0.5 \mathrm{mg} \cdot \mathrm{kg}^{-1}$, administered alone as a single bolus, significantly $(\mathrm{P}<0.05)$ decreased cardiac output, heart rate, mean arterial pressure, and significantly increased stroke volume and pulse pressure in dogs under halothane anaesthesia. Acupuncture by electrocautery alone induced a significant increase in cardiac output, stroke volume, heart rate, mean arterial pressure and pulse pressure with a significant decrease in total peripheral resistance following halothane. Acupuncture at Jen Chung (Go-26) for 10 minutes following the intravenous administration of morphine caused a significant increase in cardiac output, heart rate and mean arterial pressure with a significant decrease in central venous pressure and total peripheral resistance during halothane anaesthesia.

The depressant effect of morphine on cardiac output, heart rate and mean arterial pressure in dogs under halothane anaesthesia appears to be reversed by acupuncture by electrocautery at Jen Chung (Go-26). Stimulation of this acupuncture locus could be helpful in resuscitating patients whose cardiovascular system is depressed by morphine and/or halothane anaesthesia.
\end{abstract}

KEY WORDS: ACUPUNCTURE, Reversal of cardiovascular depression.

THE ADMINISTRATION of a small dose of morphine sulphate is not associated with significant changes in the cardiovascular system, although respiratory impairment is observed. 1.2 Larger doses of morphine produce greater depression of the respiratory center and subsequently the vasomotor center. ${ }^{1}$ The increase in carbon dioxide due to decreased respiratory function after the administration of a moderate dose of morphine is not associated with an increase in cardiac output

Do Chil Lee, M.D., Ph.D., Associate Professor, Departments of Anesthesia and Physiology; Donald $H$, Clifford, D.V.M., Ph.D., Professor and Director, Division of Laboratory Animal Medicine and Associate Professor, Department of Anatomy; Myung O. Lee, M.D., Assistant Professor, Division of Laboratory Animal Medicine; Leonard Nelson, Ph.D., Professor and Chairman, Department of Physiology; Medical College of Ohio, C.S. No. 10008, Toledo, Ohio 43699, U.S.A.

This study was partially supported by BRS Grant 5-SOI-RR-05700-08 (NIH) and the Northwest Ohio Chapter of the American Heart Association, and was conducted in conformity with the Guiding Principles in the Care and Use of Animals approved by the Council of the American Physiological Society.

Canad. Anaesth. Soc. J., vol. 28, no. 2, March 1981 and arterial pressure. This lack of response is probably due to vasomotor inhibition. A chain of parasympathetic events and reduced sympathetic activity in concert with histamine release can lead to marked peripheral dilatation, hypotension, reduced cardiac output, severe hypercapnia and death. ${ }^{1,3-7}$

The inhibition of peripheral venous constriction by morphine has been used to explain the clinical usefulness of this drug in patients with acute pulmonary oedema. ${ }^{\mathbf{g}}$ Contradictorily, other investigators have concluded that morphine may improve ventricular performance by causing sympathoadrenal discharge ${ }^{9}$ in spite of biphasic depressor responses, bradycardia and decreased respiratory rate..$^{3,10}$

Acupuncture at Jen Chung (Go-26)* produces a sympathomimetic effect on the cardiovascular system in man and animals. ${ }^{1-15}$ In comparative studies of the effects of digital pressure, needling alone, needling with twirling, needling with elec-

*This acupuncture locus, Governing Vessel-26, is also designated as (GV-26) or Renshong (Du-26). It is 129 
trical stimulation and electrocautery at Jen Chung (Go-26) in dogs under halothane anaesthesia, it was found that stimulating acupoints by electrocautery produced a greater response of the cardiovascular system than needling or other types of acupuncture. ${ }^{14-16}$ Although the stimulation of acupuncture loci with heat produces a strong effect, it has the disadvantage of burning the patient and producing a scar if not applied properly. ${ }^{17}$ This accounts for its infrequent use in human patients.

The purpose of this study was to determine the effect of morphine $0.5 \mathrm{mg} \cdot \mathrm{kg}^{-1}$ and/or acupuncture by electrocautery at Jen Chung (Go-26) on the cardiovascular system of the dog. It was anticipated that the parasympathomimetic effect of morphine could be reversed by acupuncture at a locus which is associated with a strong sympathomimetic response.

\section{Materials and Methods}

Studies were performed in 35 healthy mongrel dogs weighing from 11.5 to $20 \mathrm{~kg}$. An electromagnetic flow probe* was implanted around the ascending aorta as previously described ${ }^{13}$ and the dogs were observed for approximately ten days to insure that the probes were well tolerated. Anaesthesia was then induced with thiopentone $15 \mathrm{mg} \cdot \mathrm{kg}^{-1}$ and the trachea was intubated. The animals were maintained under light surgical anaesthesia with an inspired concentration of 0.75 per cent halothane in oxygen delivered from a Copper Kettle vaporizer. Muscle relaxation was achieved with an intravenous infusion of succinylcholine and respirations were controlled by mechanical ventilation. Approximately $30 \mathrm{mg}$ of succinylcholine were administered each hour. Mechanical ventilation with a Harvard animal respirator was used to maintain the arterial carbon dioxide between 5.31 and $6.65 \mathrm{kPa}(40-50$ torr) in the four groups. Halothane 0.75 per cent supplemented by continuous intravenous administration of succinylcholine produced reliable immobilization and permitted mechanical ventilation without inhibiting the autonomic responses. ${ }^{18-20}$ The aortic flow wave was recorded and an integral of this wave form was triggered by the electrocardiagram QRS to obtain a measure of stroke volume from each heartbeat as previously described. ${ }^{13-16}$ The femoral artery was cannulated for continuous monitoring of blood

*Zepeda, nonferrous electromagnetic flow probe, Zepeda Instruments, 1937 25th Ave., Seattle, Washington 98112 .

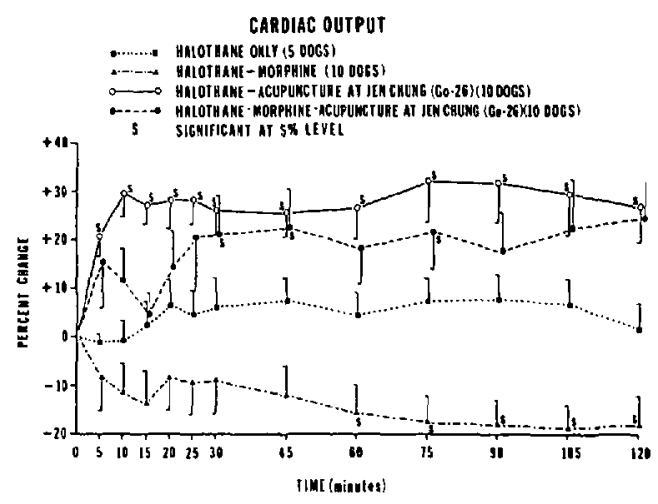

Figure 1 Cardiac output following the administration of morphine $0.5 \mathrm{mg} \cdot \mathrm{kg}^{-1}$ and/or acupuncture by electrocautery at Jen Chung (Go-26) in dogs during halothane anaesthesia. Acupuncture by electrocautery was applied for the first 10 minutes of the period of observation. The cardiac output is plotted as percent change from 0 . Absolute values $(1 / \mathrm{min})$ for 0 in the four groups are as follows: halothane alone, $2.20 \pm 0.28$; halothane-morphine, $1.62 \pm 0.14$; halothaneacupuncture, $1.88 \pm 0.09$; halothane-morphineacupuncture, $1.48 \pm 0.21$.

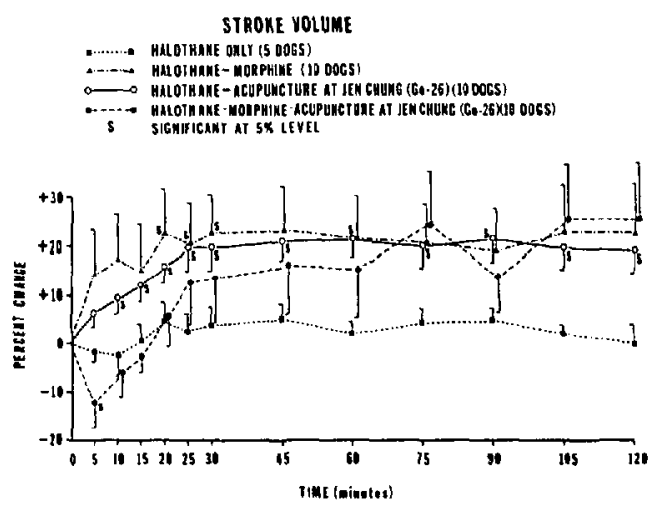

FIGURE 2 The stroke volume is plotted as per cent change from 0 as in Figure 1. Absolute values (ml/beat) for 0 in the four groups are as follows: halothane alone, $15.5 \pm 1.4$; halothane-morphine, $12.7 \pm 0.8$; halothane-acupuncture, $15.2 \pm 1.0$; halothanemorphine-acupuncture, $17.6 \pm 1.8$.

pressure with a Statham pressure transducer (P23AA). This also permitted anaerobic sampling of arterial blood for the determination of $\left[\mathrm{H}^{+}\right]$ $(\mathrm{pH}), \mathrm{Pa}_{\mathrm{CO}_{2}}$ and $\mathrm{Pa}_{\mathrm{O}_{2}}$. The heart rate was determined from the electrocardiogram.

Measurements of the haemodynamic variables were recorded every five minutes for the first 30 minutes and every 15 minutes for the ensuing 90 minutes with an Offner type RB Dynograph. Control values for each animal were determined before administration of morphine or acupuncture with electrocautery at Jen Chung 


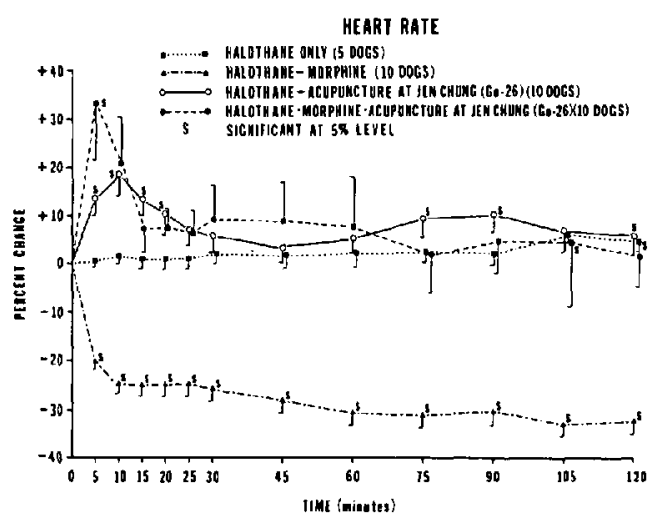

FIGURE 3 The heart rate is plotted as per cen change from 0 as in Figure 1, Absolute values (beats/min) for 0 in the four groups are as follows: halothane alone, $143 \pm 12$; halothane-morphine, $127 \pm$ 9; halothane-acupuncture, $126 \pm 6$; halothanemorphine-acupuncture, $81 \pm 6$.

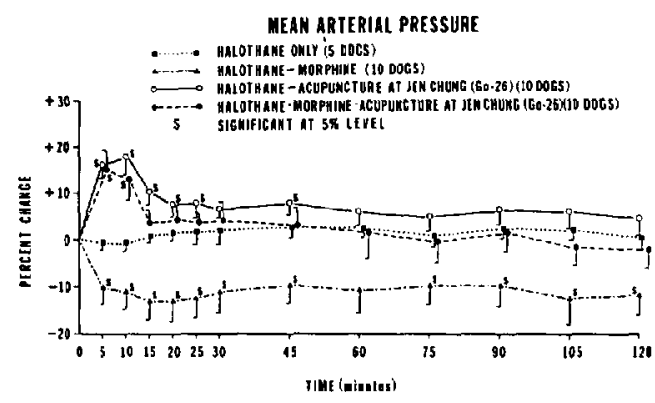

Figure 4 The mean arterial pressure is plotted as per cent change from 0 as in Figure 1. Absolute values in $\mathrm{kPa}(\mathrm{mm} \mathrm{Hg})$ for 0 in the four groups are as follows: halothane alone, $17.69 \pm 1.46(133 \pm 11)$; halothanemorphine, $13.3 \pm 0.8(100 \pm 6)$; halothane-acupuncture, $13.7 \pm 0.53 \quad(103 \pm 4)$; halothane-morphineacupuncture, $12.64 \pm 1.33(95 \pm 10)$.

(Go-26) locus; thus each animal served as its own control, which is indicated at the time 0 . Per cent change from control and absolute values are included on Figures 1-7. Oesophageal temperature was maintained at $37 \pm 1^{\circ} \mathrm{C}$. by a warming blanket and measured with a thermistor probe and Yellow Spring telethermometer. A Godart Capnograph* was used to provide continuous visual evidence that end tidal carbon dioxide was at normal level.

The acupoint Jen Chung (Go-26), which is located at midpoint of the philtrum, was determined by means of cutaneous impedance equipment, Acutest. $\dagger$ Acupuncture at this point was

*Capnograph Type KK, Godart de Bilt, Holland.

†The Acutest, designed by one of the authors, D.C.L., measures resistance of the skin to a 6-volt, 100 microamp current.

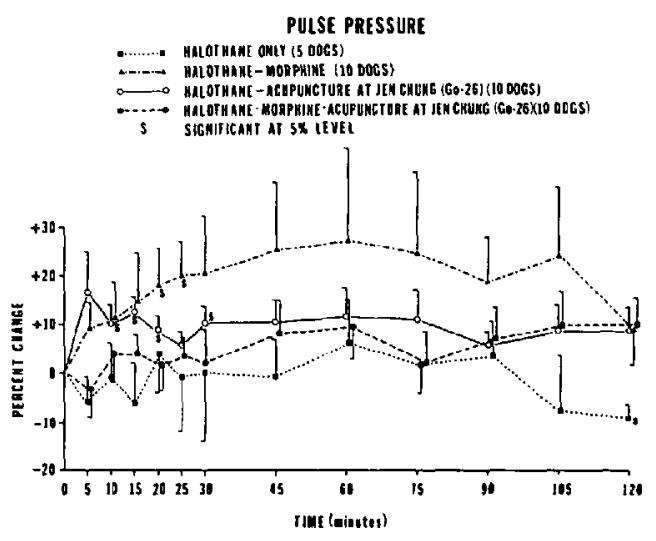

Figure 5 The pulse pressure is plotted as per cent change from 0 as in Figure 1. Absolute values in $\mathrm{kPa}$ $(\mathrm{mm} \mathrm{Hg})$ for 0 in the four groups are as follows: halothane alone, $8.11 \pm 1.2(61 \pm 9)$; halothanemorphine, $6.25 \pm 0.8(47 \pm 6)$; halothane-acupuncture, $8.91 \pm 0.27(67 \pm 2)$; halothane-morphine-acupuncture, $7.45 \pm 0.67(56 \pm 5)$.

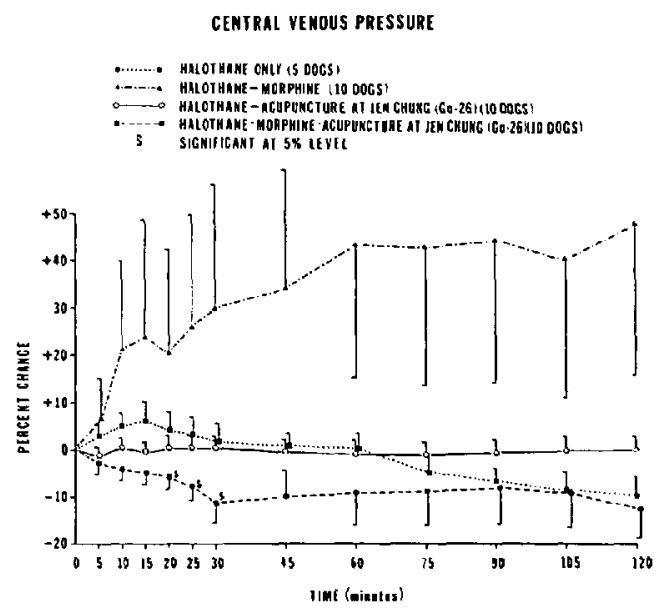

Figure 6 The central venous pressure is plotted as per cent change from 0 as in Figure 1 . Absolute values in $\mathrm{kPa}\left(\mathrm{cm} \mathrm{H}_{2} \mathrm{O}\right)$ for 0 in the four groups are as follows: halothane alone, $0.49 \pm 0.1(5.0 \pm 1.0)$; halothanemorphine, $0.49 \pm 0.08(5.0 \pm 0.8)$; halothaneacupuncture, $0.9 \pm 0.1(9.3 \pm 1.0)$; halothanemorphine-acupuncture, $0.62 \pm 0.07(6.3 \pm 0.7)$.

performed by electrocautery. The probe of the electrocautery was $3 \mathrm{~mm}$ in diameter and was maintained at $80 \pm 5^{\circ} \mathrm{C}$. It was applied for ten minutes at " 0 " time after an arterial blood sample had been withdrawn. Morphine sulphate $0.5 \mathrm{mg} \cdot \mathrm{kg}^{-1}$ was administered as a single bolus intravenously at " 0 " time immediately before acupuncture by electrocautery at Jen Chung (Go-26) for 10 minutes. The administration of morphine sulphate and acupuncture must be considered as a simultaneous event. Student's " $t$ " 


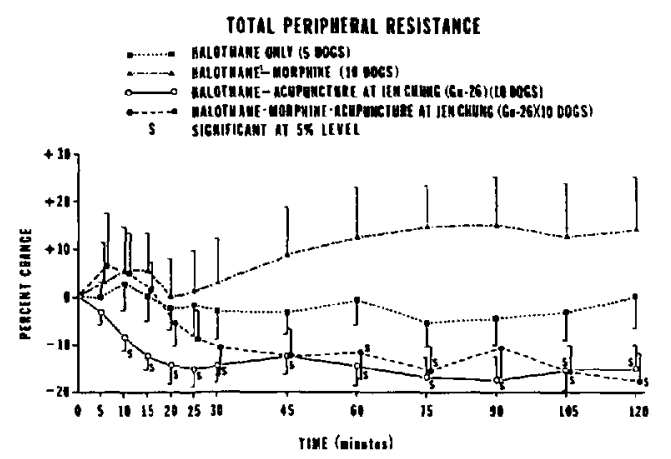

Figure 7 The total peripheral resistance is plotted as per cent change from 0 as in Figure 1 . Absolute values (dyne $/ \mathrm{sec} / \mathrm{cm}^{-s}$ ) for 0 in the four groups are as follows: halothane alone, $5200 \pm 863$; halothanemorphine, $5244 \pm 530$; halothane-acupuncture, $4506 \pm$ 380 ; halothane-morphine-acupuncture, $5922 \pm 794$.

test was used to compare values for each variable with its initial or control value.

\section{RESULTS}

The four groups of dogs included in this study are: (1) halothane alone, (2) halothane followed by morphine, (3) halothane followed by acupuncture by electrocautery, and (4) halothane followed by morphine, then acupuncture.

Seven cardiovascular variables are compared graphically (Figures 1-7). Since the $\mathrm{Pa}_{\mathrm{CO}_{2}}$ was maintained at $5.31-6.65 \mathrm{kPa}$ (40-50 Torr), the values for $\left[\mathrm{H}^{+}\right](\mathrm{pH}), \mathrm{Pa}_{\mathrm{CO}_{2}}, \mathrm{~Pa}_{\mathrm{O}_{2}}$ and base deficit were not changed significantly (Tables I-IV). Acupuncture by electrocautery at a neutral site (placebo acupuncture) was done previously without significant changes in the above cardiovascular variables. ${ }^{15}$

\section{Cardiac Output, Heart Rate and Mean Arterial Pressure}

Significant increases were observed in the cardiac output, heart rate and mean arterial pressure following acupuncture at Jen Chung (Go-26) alone and when morphine sulphate $0.5 \mathrm{mg} \cdot \mathrm{kg}^{-1}$ was administered before acupuncture (Figures I, 3, 4). Morphine alone depressed all these indices of cardiovascular performance. No significant changes were observed in the group which received halothane anaesthesia alone.

\section{Stroke Volume}

Stroke volume was significantly increased both after acupuncture alone or following morphine alone (Figure 2). Morphine followed by electrocautery caused a significant decrease in stroke volume for five minutes. It steadily improved thereafter. No consistent change was observed in the group which received halothane alone.

\section{Pulse Pressure}

Morphine alone and acupuncture alone produced a significant increase in pulse pressure which was not observed subsequent to halothane alone or acupuncture after morphine (Figure 5).

\section{Central Venous Pressure}

Central venous pressure was significantly decreased in the group in which acupuncture was performed immediately following the administration of morphine (Figure 6). Morphine alone resulted in a consistent but not significant increase in central venous pressure.

\section{Total Peripheral Resistance}

Acupuncture alone and following morphine caused a significant decrease in total peripheral resistance (Figure 7).

TABLE I

Changes in Acid-Base Values Under Halothane* Anaesthesia Alone (5 Dogs)

\begin{tabular}{|c|c|c|c|c|c|c|c|c|c|}
\hline & \multicolumn{9}{|c|}{ Time (Minutes) } \\
\hline & 0 & 15 & 30 & 45 & 60 & 75 & 90 & 105 & 120 \\
\hline$\left[\mathrm{H}^{+}\right] \mathrm{nmol} / \mathrm{l}$ & 227 & 227 & 226 & 227 & 224 & 222 & 219 & 218 & 222 \\
\hline S.E.† & 6 & 5 & 6 & 8 & 6 & 7 & 5 & 6 & 5 \\
\hline $\mathrm{PaCO}_{\mathrm{CPa}} \mathrm{kPa}$ & 5.31 & 5.19 & 5.17 & 5.19 & 5.27 & 5.27 & 5.19 & 5.15 & 5.20 \\
\hline S.E.t & 0.05 & 0.03 & 0.01 & 0.05 & 0.04 & 0.11 & 0.05 & 0.03 & 0.00 \\
\hline $\mathrm{Pa}_{2}, \mathrm{kPa}$ & 60.7 & 61.7 & 61.6 & 61.1 & 62.1 & 61.9 & 60.3 & 59.3 & 56.9 \\
\hline S.E.† & 2.5 & 2.1 & 2.0 & 1.7 & 2.9 & 3.1 & 2.8 & 2.3 & 3.6 \\
\hline Base Deficit $\mathrm{mmol} / \mathrm{l}$ & -3.0 & -3.3 & -3.6 & -3.5 & -3.4 & -3.6 & -4.3 & -4.6 & -4.0 \\
\hline S.E. $\dagger$ & 0.8 & 0.6 & 0.8 & 0.9 & 0.8 & 0.6 & 0.5 & 0.7 & 0.7 \\
\hline
\end{tabular}

${ }^{*} 0.75 \%$ halothane.

tStandard error of the mean. 
TABLE II

Changes in Acid-Base Values Under Halothane* Anaesthesia With Morphine† (7 Dogs)

\begin{tabular}{|c|c|c|c|c|c|c|c|c|c|}
\hline & \multicolumn{9}{|c|}{ Time (Minutes) } \\
\hline & 0 & 15 & 30 & 45 & 60 & 75 & 90 & 105 & 120 \\
\hline$\left[\mathrm{H}^{+}\right] \mathrm{nmol} / 1$ & 245 & 224 & 225 & 229 & 235 & 239 & 239 & 242 & 241 \\
\hline S.E. 8 & 7 & 13 & 15 & 15 & 16 & 17 & 19 & 19 & 18 \\
\hline $\mathrm{PaCO}_{2} \mathrm{kPa}$ & 5.52 & 6.52 & 6.53 & 6.39 & 6.31 & 6.13 & 5.87 & 5.83 & 5.77 \\
\hline S.E. $\$$ & 0.04 & 0.31 & 0.45 & 0.40 & 0.47 & 0.43 & 0.28 & 0.29 & 0.31 \\
\hline $\mathrm{Pa}_{0}, \mathrm{kPa}$ & 71.41 & 70.84 & 72.37 & 69.89 & 70.84 & 71.98 & 70.65 & 72.26 & 73.70 \\
\hline S.E.§ & 3.08 & 4.52 & 4.25 & 5.25 & 5.00 & 4.87 & 4.21 & 3.37 & 2.56 \\
\hline Base Deficit $\mathrm{mmol} / \mathrm{I}$ & -0.1 & -0.1 & -1.3 & -0.2 & +0.4 & +0.4 & -0.2 & -0.5 & -0.4 \\
\hline S.E. $\$$ & 0.9 & 1.3 & 1.5 & 1.0 & 1,1 & 1.1 & 1.5 & 1.4 & 1.4 \\
\hline
\end{tabular}

*0.75\% halothane.

$+0.5 \mathrm{mg} / \mathrm{kg}$ morphine.

$\$$ Standard error of the mean.

TABLE III

Changes in Acid-Base Values Under Halothane* Anaesthesia and Acupuncture† at Jen Chung (Go-26) (10 DoGs)

\begin{tabular}{|c|c|c|c|c|c|c|c|c|c|}
\hline & \multicolumn{9}{|c|}{ Time (Minutes) } \\
\hline & 0 & 15 & 30 & 45 & 60 & 75 & 90 & 105 & 120 \\
\hline$\left[\mathrm{H}^{+}\right] \mathrm{nmol} / \mathrm{l}$ & 224 & 224 & 224 & 224 & 225 & 223 & 223 & 224 & 222 \\
\hline S.E.\$ & 5 & 5 & 5 & 6 & 6 & 5 & 5 & 5 & 5 \\
\hline $\mathrm{PaCO}_{\mathrm{CPa}} \mathrm{kPa}$ & 5.31 & 5.31 & 5.28 & 5.27 & 5.29 & 5.32 & 5.39 & 5.33 & 5.33 \\
\hline S.E.§ & 0.07 & 0.05 & 0.05 & 0.07 & 0.05 & 0.04 & 0.05 & 0.05 & 0.05 \\
\hline $\mathrm{Pa}_{2} \mathrm{kPa}$ & 56.0 & 57.3 & 59.1 & 57.7 & 56.5 & 55.6 & 55.5 & 56.1 & 56.0 \\
\hline S.E.\& & 2.8 & 2.8 & 2.7 & 2.9 & 2.8 & 2.9 & 2.4 & 2.4 & 2.5 \\
\hline Base Deficit $\mathrm{mmol} / 1$ & -3.4 & -3.3 & -3.5 & -3.4 & -3.3 & -3.5 & -3.2 & -3.3 & -3.5 \\
\hline S.E.§ & 0.6 & 0.6 & 0.6 & 0.6 & 0.7 & 0.6 & 0.6 & 0.6 & 0.6 \\
\hline
\end{tabular}

*0.75\% halothane.

†Acupuncture loci were stimulated by electrocautery.

$\S$ Standard error of the mean.

TABLE IV

Changes in Acid-Base Values Under Halothane* Anaesthesia With Morphinet and Acupuncture at Jen Chung (Go-26) (5 Dogs)

\begin{tabular}{|c|c|c|c|c|c|c|c|c|c|}
\hline & \multicolumn{9}{|c|}{ Time (Minutes) } \\
\hline & 0 & 15 & 30 & 45 & 60 & 75 & 90 & 105 & 120 \\
\hline$\left[\mathrm{H}^{+}\right] \mathrm{nmol} / 1$ & 226 & 232 & 227 & 233 & 230 & 236 & 235 & 235 & 233 \\
\hline S.E. $\S$ & 21 & 25 & 18 & 18 & 18 & 23 & 24 & 24 & 21 \\
\hline $\mathrm{Pa}_{\mathrm{CO}_{2}} \mathrm{kPa}$ & 5.73 & 5.64 & 6.04 & 6.00 & 6.00 & 5.91 & 5.91 & 5.84 & 5.83 \\
\hline S.E. $\$$ & 0.60 & 0.51 & 0.51 & 0.53 & 0.51 & 0.51 & 0.52 & 0.57 & 0.44 \\
\hline $\mathrm{Pa}_{\mathrm{O}_{2}} \mathrm{kPa}$ & 65.32 & 70.21 & 68.88 & 73.32 & 74.21 & 71.09 & 69.76 & 70.21 & 71.32 \\
\hline S.E. $\S$ & 3.53 & 6.41 & 6.27 & 4.00 & 6.98 & 3.95 & 2.71 & 2.35 & 1.68 \\
\hline Base Deficit $\mathrm{mmol} / 1$ & -2.2 & -1.8 & -1.0 & -0.2 & -0.4 & -0.4 & -0.5 & -0.8 & -1.0 \\
\hline S.E. $\S$ & 1.6 & 2.2 & 1.0 & 1.3 & 1.3 & 2.2 & 1.8 & 1.7 & 1.9 \\
\hline
\end{tabular}

$* 0.75 \%$ halothane.

$\uparrow 0.5 \mathrm{mg} / \mathrm{kg}$ morphine.

$¥$ Acupuncture loci were stimulated by electrocautery.

$\S$ Standard error of the mean. 


\section{Discussion}

Halothane anaesthesia was selected for this study because it is a widely used anaesthetic agent which produces minimal centrally mediated depression of the cardiovascular functions during light surgical anaesthesia, ${ }^{21,22}$ allows the autonomic nervous system to react to a variety of autonomic drugs, ${ }^{23}$ and enables the blood gases of the animals to be controlled and maintained at a constant level by varying respirations. Acupuncture at Jen Chung (Go-26) under halothane anaesthesia produces a sympathomimetic effect on the cardiovascular system of dogs. ${ }^{13-16}$ In a previous study "placebo acupuncture' adjacent to Jen Chung (Go-26) did not result in significant changes in the cardiovascular variables included above. ${ }^{15}$ Pretreatment with either the alpha blocker phentolamine, or the beta blocker propranolol, inhibits the sympathomimetic effect of acupuncture by electrocautery at Jen Chung (Go-26). ${ }^{24.25}$ This lends additional support to the hypothesis that the effects of acupuncture at Jen Chung (Go-26) are mediated through the sympathetic nervous system.

Stimulation of the resuscitation point Jen Chung (Go-26) has been used to treat cardiorespiratory depression and shock in man and animals. ${ }^{1-13,26-28}$ In this study the depressant effects of morphine on the cardiac output, heart rate and mean arterial pressure in anaesthetized dogs were effectively inhibited by acupuncture at Jen Chung (Go-26). Thus, the sympathomimetic effects of acupuncture on the cardiovascular system appear to have predominated over the parasympathomimetic effects of morphine. It can be concluded that (1) acupuncture is not only safe but can be used effectively in resuscitating dogs under morphine-halothane anesthesia, and (2) the cardiovascular system should be observed carefully when acupuncture at Jen Chung (Go-26) is done due to its effect on this system. The possibility of using acupuncture to counteract cardiorespiratory depression produced by morphine and to improve vital functions during halothane anaesthesia should be investigated clinically.

\section{ACKNOWLEDGMENTS}

The authors wish to thank Mr. Thomas Tenney, M.S., P.E. for technical assistance, Miss Carol Perkins and Mr. Gerald Lubinski for aid with illustrations and Mrs. Patti Barrett for aid in preparing the manuscript. The authors are in- debted to Professor Lucien E. Morris for his encouragement and guidance.

The halothane (Fluothane ${ }^{(\mathbb{B})}$ was generously supplied by Ayerst Laboratories.

\section{REFERENCES}

1. Goodman, L.S. \& Gilman, A. The Pharmacological Basis of Therapeutics, 5th ed., The Macmillan Publishing Company, Inc., New York, N.Y. (1975).

2. Papper, E.M. \& Bradley, S.E. Hemodynamic effects of intravenous morphine and Pentothal sodium. J. Pharmocol. Exp. Ther. 74:319(1942).

3. FenNessy, M.R. \& RatTRAy, J.F. Cardiovascular effects of intravenous morphine in the anesthetized rat. Eur. J. Pharmacol. 14: 1 (1971).

4. Henney, R.P., Vasko, J.S., Brawley, R.F., Oldham, H.N. \& Morrow, A.C. The effects of morphine on the resistance and capacitance vessels of the peripheral circulation. Am. Heart J. 72: 242 (1966).

5. Medina, A.N. \& Bermudez, M. Hypotensive effect of morphine. Influence of histamine on acute tolerance to the drug. Arch. Int. Pharmacodyn. Ther. 188: 249 (1970).

6. Miller, R.I., Forsyth, R.P. \& Melmon, K.I. Morphine redistribution of cardiac output in the unanesthetized monkey. Pharmacology 7: 138 (1972).

7. Samuel, 1.O. \& Dundee, J.W. Circulatory effects of morphine. Br. J. Anaesth. 47: 1025 (1975).

8. Ward, J.M., McGrath, R.L. \& Weil, J.V. Effects of morphine on the peripheral vascular response to sympathetic stimulation. Am. J, Cardiol. 29: 659(1972)

9. Vasko, J.S., Henney, R.P., Brawley, R.K., OLDhAM, H.N. \& MoRROW, A.G. Effects of morphine on ventricular function and myocardial contractile force. Am. J. Physiol. 210: 329 (1966).

10. FENNESSY, M.R. The behavior, cardiovascular and respiratory actions of morphine- $\mathrm{N}$-oxide in the dog. Eur. J. Pharmacol. 8: 261 (1969).

11. Altman, S. Acupuncture as an emergency treatment. Calif. Vet. 33: 6(1979).

12. CHOE, Y.T. \& LEE, S.H. Acupuncture and Moxibustion, Meridians and Points. Ko Moon Sa, Seoul, Korea (1973).

13. Lee, D.C., Lee, M.O. \& Clifford, D.H. Cardiovascular effects of acupuncture in anesthetized dogs. Am. J. Chin. Med. 2: 271 (1974).

14. LeE, D.C., Lee, M.O. \& Clifford, D.H. Cardiovascular effects of moxibustion at Jen Chung (Go-26) during halothane anesthesia in dogs. Am. J. Chin. Med. 3: 245 (1975).

15. LEE, D.C., YoON, D.S., LEE, M.O. \& ClifFord, D.H. Some effects of acupuncture at Jen Chung (Go-26) on cardiovascular dynamics in dogs. Can. J. Comp. Med. 41: 446 (1977).

16. LEE, D.C. Comparison of the cardiovassular effects of acupuncture by various forms of stimulation in dogs during halothane anesthesia. Am. J. Acupuncture 6: 209 (1978).

17. Carron, H., Epstein, B.S. \& Grand, B. Complications of acupuncture. J.A.M.A. 228: 1552(1974).

18. SomA, L.R. Textbook of Veterinary Anesthesia, 
The Williams and Wilkins Company, Baltimore (1971).

19. Price, H.L. \& Price, M.B. Has halothane a predominate circulatory action? Anesthesiology 27: 764 (1966).

20. Shimosoto, S., LI, T.H. \& Etsten, B. Ventricular function during halothane anesthesia in the closed-chest dog. Circ. Res. 12: 63 (1963).

21. Millar, R.A.\& Briscoe, T.J. Preganglionic sympathetic activity and the effects of anaesthetics. $\mathrm{Br}$. J. Anaesth. 37: 804 (1965).

22. Wang, H.H., Epstein, R.A., MarkeE, S.J. \& Bartetone, H.J. The effects of halothane on peripheral and central vasomotor control mechanisms of the dog. Anesthesiology 29:877 (1968).

23. Clifford, D.H., LeE, M.O., Byun, K.W. \& LeE, D.C. Effects of autonomic drugs on the cardiovascular system: Dogs with achalasia (under halothane anesthesia). Am. J. Vet. Res. 38: 323 (1977).
24. LeE, D.C., LeE, M.O., Clifford, D.H. \& MoRRIS, L.E. Inhibition of the cardiovascular effects of acupuncture (moxibustion) by propranolol in dogs under halothane anesthesia. Canad. Anaesth. Soc. J. 23: 307 (1976).

25. LeE, M.O., LeE, D.C., \& Clifford, D.H. Inhibition of the cardiovascular effects of acupuncture (moxibustion) by phentolamine in dogs during halothane anesthesia. Am. J. Chin. Med. 4: 153 (1976).

26. AnoN. An Outline of Chinese Acupuncture. Foreign Language Press, Peking, (1975).

27. Frost, E.A.M. Acupuncture for the comatose patient. Am. J. Acupuncture 4: 45 (1976).

28. KHOE, W.H. The use of acupuncture in emergency cases. Am. J. Acupuncture 4: 66 (1976).

\section{RÉSUMÉ}

Les effets cardiovasculaires du sulfate de morphine et, ou de l'acupuncture électrique au point de Jen Chung (Go-26, point situé entre la lèvre supérieure et la base du nez) ont fait l'objet de cette étude effectuée chez le chien. A cet effet, 35 chiens ont été anesthésiés à l'halothane à une concentration de 0.75 pour cent et maintenus sous perfusion de succinylcholine et en respiration contrôlée durant les deux heures de la procédure. Les paramètres mesurés étaient le débit et la fréquence cardiaque, le volume d'éjection, la pression artérielle moyenne et la pression différentielle, la pression veineuse centrale et la résistance périphérique ainsi que la $\left[\mathrm{H}^{+}\right](\mathrm{pH})$, la $\mathrm{Pa}_{\mathrm{CO}}$ la $\mathrm{Pa}_{\mathrm{O}_{2}}$ et le "base excess". La morphine, seule, administrée en bolus intraveneuse à la dose de $0.5 \mathrm{mg} \cdot \mathrm{kg}^{-1}$ produisait une diminution significative $(\mathrm{p}<.05) \mathrm{du}$ débit cardiaque, de la fréquence cardiaque et de la pression artérielle moyenne et une augmentation significative du volume d'éjection et de la résistance périphérique totale de chiens anesthésiés à l'halothane. L'acupuncture électrique, seule, administrée durant dix minutes amenait une augmentation significative du débit cardiaque, du volume d'éjection, de la fréquence cardiaque, de la pression artérielle moyenne et de la pression différentielle avec une diminution significative de la résistance périphérique totale. L'acupuncture électrique administrée durant dix minutes au point de Jen Chung après l'administration intraveineuse de sulfate de morphine causait une augmentation significative du débit et de la fréquence cardiaque, et de la pression artérielle moyenne, avec une diminution significative de la pression veineuse centrale et de la résistance périphérique chez les chiens anesthésiés à l'halothane.

Les effets dépresseurs produits par la morphine sur le débit cardiaque, la fréquence cardiaque et la pression artérielle moyenne de chiens anesthésiés à l'halothane semblent donc renversés par l'administration d'acupuncture électrique au point de Jen Chung (Go-26). La stimulation de ce point d'acupuncture pourrait être utile dans la réanimation de malades au système cardiovasculaire déprimé par la morphine ou une anesthésie à l'halothane. 